\title{
DETERMINISME EN GETEMPERDE DETERMINISME IN ENKELE PSIGOLOGIESE BESKOUINGS OOR SIN EN IDENTITEIT
}

\author{
Magda van Niekerk \\ Departement Kunsgeskiedenis \\ Potchefstroomse Universiteit vir $\mathrm{CHO}$ \\ POTCHEFSTROOM
}

\begin{abstract}
One of the most fundamental questions of life is the question of meaning. The way in which man answers this, to a large extent deternines his identity. This article investigates the views on meaning and identity as implicitly or explicitly stated by representatives of psychological schools in which man's determinism is stressed rather than his freedom. I focuses on the view of man inherent in each of these approaches. The positive elements are appreciated while there is a simultaneous highlighting of the immanent problems.
\end{abstract}

\section{INLEIDING}

Die tendens dat die menslike sinproblematiek in ons eeu toenemende belangstelling wek, is 'n proses wat parallel verloop met die versnellende tempo van natuurwetenskaplike en tegnologiese ontwikkelinge. In verskeie laat-negentiende- en twintigsteeeuse filosofiese rigtings soos die eksistensialisme en die fenomenologie word reaksies aangetref op die positiwiste se ooraksentuering van die natuurwetenskappe en die siening dat die natuurwetenskaplike metode die enigste metode tot ware kennisverwerwing bied. So wys die fenomenoloog Edmund Husserl (1977:4-5) byvoorbeeld daarop dat die verabsolutering van die menslike rede sedert die Aufklärung geensins tot die verwagte utopie waarin alle mense gelukkig sou wees, gelei het nie, maar inteendee dat die sin en betekenis van die menslike bestaan skynbaar steeds verder terugwyk. Juis 'n eng natuurwetenskaplike ingesteldheid het volgens Husserl veroorsaak dat kontak verloor is met die diepste vrae wat die menslike bestaan motiveer.

Nie net filosowe nie, maar ook vele moderne psigoloë stel belang in die kwessie van menslike sinbelewing. Du Plessis (1982:15) wys daarop dat die begrip sinvolheid oor ' $n$ breë front aanvaar word as 'n motiverende faktor in menslike gedrag, as spil waarom menige patologiese toestand draai, as onderwerp van talle navorsingsprojekte en as terapeuties-implementeerbare konstruk. Hy wys ook daarop dat met behulp van psigometriese toetse bevind is dat sinvolheidsbelewing negatief met depressiwiteit en angs 
korreleer maar positief met selfaktualisering. Voorts stel hy onomwonde dat die sinproblematiek, of sinvolheidskonstruk soos hy dit noem, besonder relevant vir die omstandighede van die huidige tydsgewrig is - die heersende fokus op sinvolheidsbelewing onderstreep trouens volgens hom die dilemma van die twintigste-eeuse mens wat progressief sterker aan die angs van leegheid en betekenisloosheid onderworpe is (Du Plessis, 1982:16-17). Dit geld minstens sowel vir mense in die Verenigde State van Amerika en in Wes-Europese lande (soos die bekende psigoloog, Viktor Frankl (1969) uit jarelange ervaring met pasiënte kon berig), asook vir mense in Suid-Afrika, te meer nou dat snel veranderende politieke ontwikkelinge 'n radikale bevraagtekening van ou aanvaarde sekerhede en lewensinstellinge van veral bepaalde bevolkingsgroepe impliseer.

Ook sommige twintigste-eeuse kunstenaars beskou die sinvraag as ' $n$ uiters belangrike kwessie. So byvoorbeeld skryf die Duits-Amerikaanse samelewingskritiese kunstenaar, George Grosz (1893-1959) in 1930 in die voorwoord tot sy versamelband tekeninge onder die titel Über alles die Liebe dat die sinprobleem vir sy skeppingsarbeid van kardinale belang is:

Immer gleicht mein kritisches Bcobachten einer Frage nach Sinn, Zweck und Ziel ... aber selten giht es cine befriedigende Antwort. So setze ich meine graphischen Zeichen dafür.

Die konsep identiteit is een wat van oudsher af belangstelling gewek het. ' $n$ Inskripsie op die antieke Griekse tempel van Apollo te Delphi het gelui: 'Ken jouself'. Destyds is hieraan hoofsaaklik 'n sosiale betekenis aangaande die plek en die plig van die mens geheg. Reeds meer as twintig eeue voor die ontstaan van die Psigologie as wetenskap het Sokrates hierdie inskripsie nuut geïnterpreteer deur dit na binne te keer en met wysheid en deug in verband te bring (Allen, 1966:19-20). Beide die ouere en die nuwere interpretasie het egter die belang van selfkennis, en implisiet van die selfkonsep - wat die aandag van psigoloë in hul ondersoeke na menslike identiteit in die twintigste eeu toenemend sou boei - beklemtoon.

In die persoonlikheidpsigologie gaan dit onder andere om die struktuur, ontwikkeling en motivering van persoonlikheid. Persoonlikheidsontwikkeling hou volgens die meeste psigologiese teorieë baie nou verband met die mens se ontwikkelende identiteitsbesef. Die psigoloog se siening van motivering en struktuur hang ten nouste saam met die mensbeeld wat hanteer word, en dit weer staan in verband met ' $n$ werklikheidsopvatting wat implisiet ' $n$ antwoord op die sinvraag bevat.

Wat die beheer oor menslike gedrag betref, val die persoonlikheidsteorieë uiteen in twee hoofkategorieë. Enersyds is daar die teorieë waarin besondere klem gelê word op die gedetermineerdheid van die menslike gedrag, hetsy deur onbewuste drange, eksterne omgewingsfaktore of fisiologiese en biologiese faktore. Dit omvat veral die 
dieptepsigologie en behaviorisme. Andersyds is daar die sogenaamde fenomenologiese, eksistensiële en humanistiese psigologiese teorieë wat eerder klem lê op die mens se vrye wilskeuse, selfdeterminering en selfaktualisering. Omdat psigoloë egter in konfrontasie met die werklikheid en met 'n verskeidenheid teorieë mettertyd bewus raak van leemtes en eensydighede in bestaande teorieë, vind daar dikwels ook kruisbeïnvloeding tussen beskouings van hierdie hoofkategorieë plaas en kom daar geleidelik ' $n$ groter genuanseerdheid in psigologiese beskouinge na vore. Dit beteken dat die reduksionisme van uiteenlopende psigologiese tradisies tans in 'n groot mate getemper is en dat 'n integrasie tussen die insigte van verskillende standpunte en denkskole plaasgevind het. Dit loon nogtans die moeite om kennis te neem van die herkoms van verskillende opvattings aangaande sin en identiteit, ten einde meer gemotiveerd ' $n$ eie standpunt te kan inneem in aansluiting by 'n bepaalde rigting of rigtings. Daar word dus eerstens ${ }^{1}$ ondersoek ingestel na standpunte oor die kwessies van sin en identiteit, soos na vore kom in dieptepsigologiese en behavioristiese benaderings, sowel as in enkele nuwere rigtings wat enersyds hierop voortbou, maar tog nader kom aan ' $n$ meer 'humanistiese' siening. ${ }^{2}$

\section{DIEPTEPSIGOLOGIESE BYDRAES}

Volgens Sigmund Freud se psigiese determinisme is die motivering vir gedrag geleë in die onbewuste wat alle ontoelaatbare, onaanvaarbare en daarom verdronge ervarings en begeertes huisves (Freud, 1972:237-289). Hierdie onbewuste drange geld as diepste motiverings vir menslike handelinge en funksioneer volgens Freud na aanleiding van die beginsel van homeostase, met ander woorde die mens strewe na die bevrediging van onbewuste drange ter wille van spanningsvermindering. 'n Kompromis tussen die behoeftes tot onmiddellike drangbevrediging en die eise van die werklikheid kom normaalweg tot stand deur die ontwikkeling en werking van die ego, terwyl die superego met sy geïnternaliseerde waardes daarvoor verantwoordelik is dat die bevrediging geskied in ooreenstemming met morele, godsdienstige en ander samelewingsnorme.

Möller (1987:48) wys egter tereg daarop dat, benewens die feit dat die mens in sy optrede allermins altyd ingestel is op spanningsvermindering maar dikwels juis

\footnotetext{
1 In 'n volgende artikel sal (DV) aandag gegee word aan dic vraag of die sogenaamde humanislicse, fenomenologiesc en eksistensiële benaderings in dic psigologic vir die Christen 'n werklike alternatief bied vir dic delerministiese beskouings wat in hierdie artikel bespreck word.

2 Die woord 'humanisties' word tussen aanhalingstekens geplaas, omdat dit in 'n ietwat enger sin bedocl word as wat gebruiklik is in ' $n$ reformatoricse denktradisic waar al die tcorieë wat in hicrdic artikel bespreek word, breedweg as humanisties getipeer sou word.
} 
stimulering soek en dat dit spanningsvermeerdering impliseer, Freud se biologiese determinisme nie voorsiening maak vir die tipiese keusevryheid van die mens, ${ }^{3}$ sy toekomsgerigtheid of die invloed van huidige faktore op gedrag nie.

Juis weens die eensydighede wat vervat is in Freud se beskouing dat biologiese energie die basiese dryfkrag van die menslike persoonlikheid uitmaak, het latere dieptepsigoloë soos Jung bepaalde verstellings in sy teorieë aangebring en dit gekombineer met oorspronklike nuwere bydraes. Van belang vir die doeleindes van hierdie artikel is Jung (1954:75) se beskouing aangaande die menslike self wat hy onderskei van die $I c h$. Die self omvat die ek, en die ek is die sentrum van die menslike bewussynsveld en subjek van alle persoonlike akte. Dit waarvan die mens bewus is, staan altyd in verbinding met die ek, sodat die ek as "Bewusstsein überhaupt" gedefinieer word (Jung, 1954:78) en dié deel van die mens is wat oor keusevryheid beskik. Die self, daarenteen, word egter begrens deur die noodwendighede van die sosiale omgewing en die feitelikhede van die self (Jung, 1954:79). Die self is volgens Jung (1954:78) die totale persoonlikheid, wat ook die persoonlike en die kollektiewe onbewuste insluit en dikwels daardeur gedetermineer word. Hier word dit duidelik dat die Freudiaanse determinisme in Jung se mensbeeld tog steeds 'n onmiskenbare invloed het.

'n Opvatting van Jung waarby aangesluit kan word, is sy beskouing dat persoonlikheidsveranderinge nie patologies hoef te wees nie, maar ook normaal kan wees in soverre hulle ontwikkelingsbepaald is (Jung, 1954:79). Die normale mens het dus volgens Jung 'n relatiewe identiteit wat ook vir verandering ruimte laat. Met hierdie standpunt weerspieël Jung sensitiwiteit vir die beginsel van kontinuïteit in identiteitsvorming, wat sekerlik in 'n reformatoriese ontwikkelingsteorie sterk behoort te figureer. ${ }^{4}$ In sy beskouing dat hierdie self in noue verband staan met die mens se godsdiens en met transendentale ervarings, stuit hy in der waarheid op die religieuse gerigtheid van die mens, wat op Bybelse standpunt verreken moet word, terwyl sy klem op doelstellings en op die mens se skeppende potensiaal 'n meer optimistiese mensbeeld en 'n tempering van Freud se deterministiese menssiening verteenwoordig. Meyer (1985:116) wys in hierdie verband daarop dat, terwyl Freud identiteitsontwikkeling deterministies verklaar vanuit die onbewuste dranglewe, latere dieptepsigoloë reeds die mens se

\footnotetext{
3 Fromm (1965:126) vestig dic aandag daarop dat vryheid volgens Freud bestaan in die mens se bewustheid van die kragte wat hom determineer, waarteen hy vervolgens 'n stryd kan aanknoop in 'n optimale verwerkliking van sy vryheid.

4 Kontinuïteit is saam met ander norme soos differensiasie en integrasie algemene historiese norme (Dooyewecrd, 1955:243, 260-261) wat ook in die vorming van die menslike persoonlikheid gepositiveer word.
} 
strewe na toekomsgerigte ideale beklemtoon het en hierin vooruitgewys het na die humanistiese psigologiese teorie. ${ }^{5}$

Adler (1950:21) ag die persoonlike sin-opvatting van die mens as van kardinale belang:

De opvalting van een bepaald persoon over de zin van het leven is van groot gewicht, want zij is het richtsnoer voor zijn denken, voelen en handelen. De ware zin van het leven komt tot uiting in de weerstand, die de werkelijkheid aan het onjuiste handelen biedt.

Hieruit blyk dat Adler onderskei tussen 'n objektiewe sin van die werklikheid, en 'n subjektiewe sin-opvatting van die individuele mens, 'n onderskeid waarby ook op Christelike standpunt positief aansluiting gevind kan word. Objektiewe sin word egter deur hom op humanistiese wyse vereenselwig met die algemene welsyn van die gemeenskap (Adler, 1948:3-24) en die mens wat nie hiertoe bydra nie, lei 'n siniose lewe (Adler, 1950:198). Hierdie beskouing dui weliswaar op die belang van die naasteliefde, maar dit weerspieël geen besef van die verband van ware naasteliefde met 'n religieuse gerigtheid op God nie. En Adler se utopie van 'n mensheid met 'n volmakkte gemeenskapsgevoel is een wat nog in hierdie bedeling bereik kan word:

Wij mogen verwachten, dat in een verre toekomst, mits aan de mensheid genoeg tijd wordt gelaten, de kracht van het gemeenschapsgevoel over alle uitwendige weerstanden zal zegevieren. (Adler, 1950:203.)

Binne die kring van sosiaal-psigologiese dieptepsigoloë word die klem by die vorming van menslike identiteit geplaas op sosiaal-maatskaplike en opvoedkundige faktore. Horney (1947:79-89) beklemtoon byvoorbeeld die ouer-kindverhouding waarin die kind 'n lewensbelangrike basiese sekuriteit ontwikkel, waarsonder basiese angs en 'n neurotiese persoonlikheid sy voorland is. Sy skenk ook aandag aan die invloed van verskillende neurotiserende faktore (teenstrydighede in verwagtings, ensovoorts) van die samelewing op die individu (Horney, 1947:281-290).

Ook hier moet toegegee word dat dergelike faktore 'n negatiewe uitwerking op die menslike persoonlikheid en psigiese welsyn kan hê, maar in dieselfde mate as wat hierdie invloede deterministies gedui word, word daar 'n streep getrek deur die menslike keusevryheid met verantwoordelikheid teenoor God, en is die ondersoeker vanuit 'n reformatoriese antropologie genoodsaak om hom/haar hiervan te distansieer.

\footnotetext{
5 Vergelyk ook reeds Adler (1948:14) se klem op die menslike vryheid waardeur hy sin en betckenis aan sy crvarings kan gee.
} 
Fromm (1965) poog om Freud se meganisties-materialistiese teorieë in 'n groter dialekties-humanistiese (Fromm, 1965:14) verwysingsraamwerk te plaas, ter wille waarvan Ruth Anshen (1965:7) in haar inleiding tot Fromm (1965) die mens se sinsoeke en samehangende probleme beklemtoon:

Confronted with the question of meaning, he (man - MvN) is summoned to rediscover and scrutinize the immutable and the permanent which constitute the dynamic, unifying aspect of life as well as the principle of differentiation, to reconcile identity and diversity, immutability and unrost.

Dit wil dus voorkom asof Anshen die sinvraag in verband bring met 'n samehindende kern van die persoonlikheid wat meebring dat verandering en differensiasie in ooreenstemming met 'n relatief stabiele, dog dinamiese identiteit plaasvind. Dit is voorwaar 'n beskouing wat besondere moontlikhede vir die Christenpsigoloog inhou. Dit bevat elemente waarby in 'n groot mate aansluiting gevind kan word, nie die minste nie die aanduiding van die verband tussen die sin- en identiteitsproblematiek.

Fromm (1965:117) sien die mens in 'n voortdurende konfliksituasie tussen vryheid en determinisme, wat hy Freudiaans interpreteer as 'n "conflict of inclinations" (Fromm, 1965:128). Omdat hy hom tot psigoanalitiese ervarings wend ter verklaring van menslike vryheid (Fromm, 1965:124), kom sy vryheidsopvatting in konflik met ' $n$ ander vryheidsopvatting wat hy tegelykertyd probeer handhaaf, naamlik dat hy wat nie vry is om dic kwaad te kies nie, die werklike vrye persoon is (Fromm, 1965:132). Met laasgenoemde opvatting stuit hy op die ware aard van vryheid as 'n op God gerigte gebondenheid aan die skeppingsraamwerke wat deur God daargestel is. Ook hierdie vryheid bly egter vir Fromm 'n geneigdheid wat afhanklik is van die interaksie van kragte in die individu.

\section{EGOPSIGOLOGIE}

Die egopsigologie weerspieël in 'n groot mate die invloed van die dieptepsigologie van Freud, ook in die aanvaarding van dieselfde strukturele model van die persoonlikheid naamlik die id, ego en superego. Hiernaas kom egter ook belangrike verskille na vore, wat dui op ooreenkomste met die 'humanistiese' benaderings.

In die ontwikkelingpsigologie word daar onder andere deur die egopsigoloog Erikson (1980, 51-107) uitvoerig aandag gegee aan die vorming van identiteit by die mens. Hy doen dit in die konteks van sy onderskeiding van 'n agttal ontwikkelingstadia waardeur die mens in interaksie met sy omgewing vanaf sy geboorte tot by bejaardheid gaan. $\mathrm{Hy}$ 
koppel aan elk van hierdie stadia 'n bepaalde hoofdoel wat, indien dit nie bereik word nie, onsuksesvolle krisisoplossing in die betrokke stadium impliseer, wat dan weer in latere stadia probleme oplewer.

$\mathrm{Na}$ die laerskooljare waarin die kind se selfkonsep reeds in 'n mate begin vorm aanneem, bereik die mens die stadium van adolessensie, wat volgens Erikson juis die tydperk is waarin 'n soeke na identiteit by uitstek na vore kom. Hierdie identiteitsontwikkeling beskou Erikson as die belangrikste faset van menslike persoonlikheidsontplooiing, en die verwerwing van 'n eie identiteit as 'n belangrike keerpunt in die lowe van die mens. In hierdie fase moet die jongmens sy rol in die lewe vind (wat dikwels met 'n beroepskeuse geassosieer word) onafhanklik van sy familie en moet hy sy persoonlike standpunt ten opsigte van die waardes van die gemeenskap definieer. Hy moet ook in homself ' $n$ antwoord verkry op die vraag wie hy is, tot watter groep hy behoort (sy sosiale identiteit), watter ideale hy koester en wat hy in die lewe wil bereik (Erikson, 1980:127-128). Indien hy hier misluk, tree rolverwarring in en verkry hy geen persoonlike identiteit nie, ly hy dus onder identiteitsverwarring, met die gevolg dat hy in 'n afhanklikheidsverhouding van sy familie of van 'n bepaalde groep of subkultuur bly leef. Suksesvolle krisisoplossing in hierdie stadium lei volgens Erikson daartoe dat die jongmens betroubaarheid as persoonlikheidseienskap ontwikkel.

In aansluiting by Erikson kan gekonstateer word dat die ontwikkeling van 'n positiewe selfbeeld en eie identiteit gedurende adolessensie (waarvoor'n deurlopende goeie verhouding met die ouers, een van liefde en respek, en met die portuurgroep, een van agting en ondersteuning noodsaaklik is) lei tot 'n stabiele, volwasse persoonlikheid, terwyl onbevredigende antwoorde op die identiteitsvraag aanleiding kan gee tot aanpassingsprobleme in die latere lewe. Terwyl Erikson die aanleiding tot die krisis van die adolessent veral soek in die biotiese en psigiese veranderinge wat met puberteit intree, is daar by hom egter weinig sig op die ontwikkelende religieuse selfsiandigheid van die jongmens en interpreteer hy die vrae en probleme wat met adolessensie gepaard gaan, sekerlik nie vanuit hierdie perspektief nie.

Op die suksesvolle oplossing van die hoofprobleme in adolessensie volg volgens Erikson die strewe na intimiteit, stabiliteit en sosialisering met 'n wye groep mense in die fase van vroeë volwassenheid. Onsuksesvolle krisisoplossing lei hier tot isolasie. Wanncer die middeljare aanbreek, kan die mens normaalweg reeds in ooreenstemming met die aanvaarde identiteit wat teen die helfte van sy twintigerjare sy deel bchoort te wees, 'n vrugbare en produktiewe lewe volgens transpersoonlike waardes lei, tot voordeel van homself en van die gemeenskap. Volgens Erikson het die vol- 
wasse mens die taak om generatief te wees. Generatiwiteit dui onder andere op produktiwiteit, kreatiwiteit en kultuuroordrag, waardeur hy vir homself en vir ander die lewe verryk. Dit veronderstel egter 'n geloof in die sinvolheid van die lewe, die waarde van die mens en die toekoms van die mensheid, sodat 'n persoon wat die krisis van hierdie stadium nie suksesvol hanteer nie, faal om die eienskap van sorgsaamheid te ontwikkel en neig om te stagneer in pessimisme in en in 'n beheptheid met homself. By gebrek aan produktiwiteit tydens die middeljare, loop die mens gevaar om in 'n groef te beland en te stagneer, iets wat aanleiding kan gee tot depressie en tot die gevoel dat die lewe by die mens verbygaan. In hierdie fase vind ook 'n vergelyking plaas van die mens se lewensdoelwitte met dit wat hy bereik het. 'n Ernstige krisis tydens die middeljare berus dikwels op die selfevaluasie dat die persoon gefaal het in dic bereiking van sy ideale en dit kan soms lei tot 'n teruggrype na die jeug as teenvoeter teen stagnasie.

Effektiewe krisisoplossing tydens die middeljare bring egter 'n nuwe rypheid en lewenservaring mee. Die laaste fase van die menslike persoonlikheidsontwikkeling is dié van bejaardheid waartydens, volgens Erikson, die mens sy hele lewensloop in perspektief beskou en vasstel of hy iets van blywende waarde bereik het al dan nie. Indien wel, ervaar die mens 'n gevoel van wysheid, maar indien nie, 'n gevoel van wanhoop en depressie. Die persoon wat in bejaardheid nie met tevredenheid op sy lewe terugkyk nie, mis wysheid of ego-integriteit as gevolg van 'n gebrekkige krisisoplossing tydens bejaardheid, wat deels mag berus op 'n onbevredigende krisishantering tydens volwassenheid.

Erikson (1980:22) onderskei tussen 'n persoonlike identiteit en 'n ego-identiteit ${ }^{6}$. Die persoonlike identiteit is volgens hom gebaseer op die mens se besef dat hy steeds dieselfde persoon bly, nieteenstaande veranderinge in die tyd, en dat hy as sodanig deur ander erken word. Hy stel dit soos volg:

What I propose to call ego identity concerns more than the mere fact of cxistence, as conveyed by personal identity; it is the ego quality of this existence. (Erikson, 1980:22.)

Die volgende opmerking van hom toon ewe-eens dat hy verskillende dimensies van identiteit onderskei:

Ego identity, then, develops out of a gradual integration of all identifications, but here, if anywhere, the whole has a different quality from the sum of its parts. (Erikson, 1972:203.)

\footnotetext{
${ }^{6}$ Erikson se terme is enigsins ongelukkig, want wat kan nou meer 'persoonlik' wees as dic egoidentiteit, wat juis onderskei word van die persoonlike identiteit. Laasgenoemde kan miskien cerder individualiteit of individucle identiteit genoem word.
} 
Hierby bedoel hy skynbaar ' $n$ dimensie van identiteit wat dieperliggend is, die uitkristallisering van 'n basiese lewensingesteldheid veral tydens adolessensie, sodat daar inderdaad positief aangesluit kan word hierby, soos ook by etlike ander fasette van sy teorie. Die mens se vraag na sy sosiale identiteit en, vir sover dit dui op bepaalde kortof langtermyndoelwitte, ook die vraag na sy eie ideale, maak beslis deel uit van sy identiteit op 'n sekondêre vlak, al sou dit dan ook nog nie 'n antwoord verskaf op die vraag wie en wat die mens ten diepste is nie. Indien die vraag na lewensideale egter in 'n herinterpretasie van Erikson se beskouings gedefinieer word as die sinvraag, met ander woorde die oorkoepelende lewensvraag, dui dit op die soeke na lewensrigting wat direk in verband staan met die mens se diepste religieuse vertrekpunte en dus met sy identiteit op 'n dieper vlak. Met Erikson se siening van die adolessent se oplossing van die identiteitskrisis, wat bestaan in die bereiking van betroubaarheid as 'n sintese tussen identiteit en identiteitsverwarring, gee hy op sy manier rekenskap van die integrasie van die persoonlikheid by beantwoording van die vraag na 'n dieper identiteit, waardeur volgens 'n Bybelse mensbeeld die hartsgesteldheid die lewensuitgange van die mens bepaal.

Hoewel die kritiek soms geuiter word dat Erikson se beskouings "slegs enkele aspekte van menslike ontwikkeling dek, naamlik veral die mens se basiese ingesteldheid teenoor ander mense en die lewe" (Meyer, 1985:122), behoort hierdie klem op 'n basiese lewensingesteldheid na my mening eerder positief geëvalueer te word, aangesien dit in ' $n$ groot mate bepalend is vir sake soos kognitiewe en emosionele ontwikkeling en dus nie bloot as 'n enkele aspek van ontwikkeling gesien kan word nie.

As egopsigoloog begrond Erikson sy siening van identiteit op 'n wyse wat sowel verwant is aan die klassieke Freudiaanse antropologie, maar ook daarvan verskil, aangesien die ego volgens hom 'n selfstandiger rol vervul as by Freud en ook gedrag kan inisieer, sodat by hom die determinisme in die mensbeeld van die dieptepsigologie aansienlik getemper word. Hy hanteer egter geensins 'n Bybelse mensbeskouing waarin die implikasies van die mens se religieuse bepaaldheid vir die aard van sy identiteit na vore kom nie, maar lê veeleer besondere klem op die mens se sosiale omgewing wat in interaksie met die ontwikkelende persoon aan hom uitdagings stel en sodoende sy identiteitsvorming beïnvloed.

\section{BEHAVIORISME EN NEO-BEHAVIORISME}

In die klassieke behavioristiese teorieë word die probleem van identiteit op 'n ander manier as by die Freudiaanse teorieë, maar ewe-eens deterministies gedui, en wel as 
aangeleerde eienskappe (konstante response) van die persoon in wisselwerking met sy omgewing of as fisiese liggaamsveranderinge wat prikkels of stimuli verskaf. Die klem val op waarneembare gedrag en op die leerproses wat deur middel van prosesse soos kondisionering en modellering plaasvind. Die bewussynservaringe wat tussen die stimulus en die reaksie gebeur, word ewe-eens aan fisiese en/of biotiese funksies toegeskryf (indien nie as ontoeganklik vir wetenskaplike ondersoek verwerp nie).

Die onrsaaklikheidsverband tussen prikkel en respons verteenwoordig 'n meganistiese mensbeskouing wat vir menslike vryheid weinig indien enige ruimte laat. As dogmatiese behavioris het John Watson, die grondlegger van hierdie rigting in die Psigologie, sowel as latere navolgers soos B.F. Skinner klaarblyklik belangrike fasette van menslike ervaring buite rekening gelaat ${ }^{7}$ of tot fisies-biotiese prosesse en kondisionering of omgewingsinvloede herlei, 8 met die gevolg dat neo-behavioristiese teoriee na vore gebring is wat groter klem laat val het op tipies menslike kwaliteite soos doelstellings, die selfkonsep, uniekheid, motiverings, waardes, vorige ervarings, kennis, emosies, ensovoorts.

Tekenend van die diepgaande verskille tussen die behaviorisme en latere humanistiese rigtings in die Psigologie is Allport $(1961: 96,107)$ se reaksie op die behavioristiese verklaring van gedrag as response op stimuli, wat as gevolg van versterking vasgelê word. Hy wys naamlik daarop dat 'n persoon sake wat vir hom van sentrale belang is, kan leer sonder dat enige versterking daarby 'n rol hoef te speel. Ook vanuit eie standpunt moet duidelik gestel word dat, hoewel die omgewing in sosiale en opvoedkundige sin bepaalde aksente in die funksionering van die menslike aktstruktuur mag lê en 'n diepgaande invloed op die mens se lewenshouding mag uitoefen, dit nie sy totale gedragspatroon en sy religieuse rigting deterministies kan bepaal nie. Menslike gedrag mag vanuit 'n Christelik-antropologiese standpunt nooit reduksionisties as 'n samestelling van stimuli en response verklaar word nie. Die leerteorieë bied juis om hierdie rede oor die algemeen weinig aanknopingspunte vir 'n sinvolle beskouing oor die kwessie van identiteit indien dit vanuit 'n reformatoriese antropologie of ook gedeeltelik vanuit 'n humanistiese benadering as noodsaaklik ervaar word om identiteitsvorming met die sinvraag en/of met rigtinggewende ideale in verband te bring.

\footnotetext{
7 Watson (1925:200) sê byvoorbecld ondubbelsinnig: "The premises of the behaviorist contain no propositions about meaning. It is an historical word borrowed from philosophy and introspective psychology."

8 Kyk Skinner (1972a) in verband met die behavioristicse siening van vryheid, waardigheid, verantwoordelikheid, waardes ensovoorts, asook Skinner (1972b:333-344) vir 'n tocpassing van sy meganistiese uitgangspunte op die kreatiewe gedrag van dic kunstenaar.
} 
Die neo-behavioriste reageer teen die behavioriste se klem op waarneembare gedrag as response op stimuli en teen laasgenoemde se oorbeklemtoning van behoeftebevrediging en van versterking ter verklaring van gedrag (Kelly, 1963:158). Binne hierdie kader skenk kognitiewe psigoloë soos George Kelly en Albert Ellis besondere aandag aan die mens se kennis, gedagtes of idees wat as gedragsbepalend gesien word. Kelly (1963:15) beskryf sy eie uitgangspunt as een van "konstruktiewe alternatiwisme", wat beteken dat geen mens die slagoffer van sy lewensloop hoef te wees nie, aangesien alle menslike interpretasies onderworpe is aan vervanging of hersiening deur middel van alternatiewe sienings van omstandighede, soos gekontroleer in 'n 'wetenskaplike' aanpak. Dit val op dat Kelly hiermee nie net nader kom aan die 'humanistiese' rigtings in die Psigologie nie, maar dat sy beskouings in die tradisie van die rasionalisme staan.

Volgens Kelly interpreteer of konstrueer die mens alle ervarings subjektief aan die hand van persoonlike konstrukte, idees of abstraksies waarmee die individu vir homself $\sin$ daarstel in die warboel van feite en situasies, terwyl konstrukte weer slegs sin het in hul toepassing op konkrete gebeurtenisse (Kelly, 1963:122). Hierdie konstruksies hoef nie noodwendig geverbaliseer te word nie, maar moet wel op een of ander wyse geabstraheer word om as algemene riglyne vir huidige en toekomstige gedrag gehanteer te word (Kelly, 1963:173). Konstrukte word dan, soos in die werkwyse van 'n wetenskaplike, weer in daaropvolgende ervarings as hipoteses gehanteer, getoets en geverifieer of uitgebou, gewysig of selfs verwerp (Kelly, 1963:14). ${ }^{9}$ Sodoende bou die mens vir homself 'n omvattende konstruksiesisteem op, aan die hand waarvan die wêreld as geheel beleef word, individuele gebeurtenisse verklaar en toekomsvoorspellings gemaak word (Kelly, 1963:12-14).

Vir die doeleindes van die tema moet kennis geneem word van die feit dat konstrukte volgens Kelly (1963:142-143) hiërargies georden en aanmekaar geskakel is, sodat konstrukte van 'n laer orde as ondergeskikte elemente binne die samehang van kon. strukte van 'n hoër orde funksioneer (Kelly, 1963:57, 78). Laasgenoemcle tipe konstrukte staan sentraal in die individu se persoonlikheidsfunksionering, en as voorbeeld hiervan noem Kelly (1963:126) 'n persoon se geloof in God en sy fundamentele lewensheginsels (Kelly, 1963:78). Konstrukte van 'n laer orde, ook genoem randkonstrukte (Möller \& Louw, 1987:93) is egter van veel minder belang en daarom ook makliker veranderbaar of deurdringbaar as kernkonstrukte, met ander woorde konstrukte van 'n

\footnotetext{
"Soos 'n gocic Verligtingsdenker, laat hy dus ook nic die idcaal van empirisisme en eksperimentalisme, dic ander grondtendens van die Verligtingstyd naas rasionalisme, los nic vergclyk ook sy cic uitcensctting van sy filosofiese uitgangspunte (Kelly, 1963:17, 122).
} 
hoër orde (Kelly, 1963:59), terwyl laasgenoemde juis aan die menslike persoonlikheid konsistensie verskaf (Kelly, 1963:89). Hy (Kelly, 1963:55-56) omskryf individualiteit in terme van die unieke konstruksiesisteme van individue, want individue verskil van mekaar as gevolg van die onderskeid in hul konstruksie van gebeurtenisse en in hul hiërargiese rangskikking van konstrukte.

Juis in hierdie beskouing van kern- en randkonstrukte gee Kelly blyke van 'n besef van die onderskeid tussen verskillende dimensies van identiteit, waarvan ook in 'n reformatoriese beskouing rekenskap gegee sal moet word. Seifs sy kernkonstrukte bly egter blote rasionele, abstrakte konsepte wat nie noodwendig enige religieuse gerigtheid van die hart impliseer nie, maar vasgelê word deur omgewingsinvloede en rasionele of irrasionele menslike reaksies daarop en interaksies daarmee. Terwyl Kelly (1963:131) duidelik stel dat die konsep van die self vanuit aktuele gebeurtenisse gekonstrueer en vervolgens as 'n kernkonstruk gehanteer word, impliseer dit 'n oortrokke klem op waarneembare gedrag en gebeurtenisse, wat blyke gee van die verbintenis van sy kognitiewe psigologie met die behaviorisme:

It (the sclf - MvN) refers to a group of events which are alike in a certain way and, in that same way, necessarily different from other events. The way in which the events are alike is the self. That also makes the self an individual, differentiated from other individuals. The self, having thus been conceptualized, can now be used as a thing, a datum, or an item in the context of a superordinate construct.

Hiermee word menslike identiteit gereduseer tot die grootste gemene deler van 'n aantal gebeurtenisse en is dit weinig meer as 'n teoretiese konstruk.

Kelly se bydraes oor individualiteit kan egter waardeer word, met dien verstande dat die beperkende invloed van sy filosofiese uitgangspunte verreken moet word. ${ }^{10}$ Voorts dui sy fundamentele postulaat of hipotese dat die mens se handelinge bepaal word deur die wyse waarop hy gebeurtenisse antisipeer (Kelly, 1963:46-47, 157) op 'n erkenning van die belang van toekomsgerigtheid in die lewe van die mens, wat sekerlik 'n bepaalde regstelling is van Freudiaanse en klassiek-behavioristiese beskouings. In soverre as wat hierdie teorie egter in sy geheel 'n oorbeklemtoning van bewuste rasioneic aspekte ten koste van emosionele en ander menslike funksies impliseer, sodat aan die mens in sy alledaagse lewe 'n kwasi-wetenskaplikheid (vergelyk Kelly, 1963:12, 120) toegedig word, kan nie hiermee saamgestem word nie. Daarby is hierdie kognitiewe toekomsgerigtheid kwalitatief anders as 'n eskatologiese visie in Bybelse sin.

\footnotetext{
10 Immers, ook die mens se hiërargiese rangskikking van konstrukte en sy konstruksic en antisipasie van gebeurtenisse, hoe belangrik ook al, kan slegs werklik begryp word vanuit 'n religicuse perspekticf.
} 
Teenoor die behavioriste het ook Ellis (1979:16) in sy sogenaamde ABC-model waar A verwys na omgewingsgebeurtenisse, B na die individu se oortuigingsisteem, sy denke, waardes, houdings of lewensfilosofie en $\mathbf{C}$ na die emosionele gevolge en gedrag van die persoon, die klem by menslike motivering geplaas op die interne lokus van kontrole, binne bepaalde grense soos bepaal deur oorerflikheid (Ellis, 1979:17). Dit impliseer dat eksterne omstandighede weliswaar die mens se gedrag kan beïnvloed, maar nie kan determineer nie, omdat laasgenoemde geskied op die basis van die persoon se evaluering van gebeurtenisse. 'n Mens kan rasioneel of irrasioneel oor gebeure dink, maar irrasionele denke, wat psigiese versteurdheid veroorsaak, is essensieel onrealistiese en onverifieerbare opvattings oor die werklikheid (Ellis, 1979:63).

Hoewel sin en identiteit nie konsepte is wat uitstaan in Ellis se teorieë nie, impliseer sy beskouings tog dat die mens se identiteit hoofsaaklik bepaal word deur sy rasionele en/of irrasionele kognisies, en dat sin geleë is in 'n toename aan rasionaliteit, wat vir die mens psigiese gesondheid waarborg. In sy klem op die interne lokus van kontrole en op die mens se persoonlike verantwoordelikheid om in sy interpretasie van gebeurtenisse reg te laat geskied aan die werklikheid, kan beslis met Ellis saamgestem word, met dien verstande dat hierdie 'werklikheid' deur die reformatoriese denker nie vereenselwig mag word met 'n gewaande objektiewe feitelikheid nie, maar gedra moet word deur 'n Bybelse grondmotief van skepping, sondeval en verlossing deur Christus. Ellis (1979:9-15, 69) se waarneming dat irrasionele denke onder andere vergesel word deur absolutistiese denke, negatiewe selfbeoordelings, katastroferings, oorveralgemenings, oordramatiserings, ' $n$ verdedigende houding en weerstand teen verandering, is sekerlik waardevol, maar hy staan steeds op immanensiestandpunt as hy hierdie dwalings as denkfoute tipeer, sonder om aan die religieuse dieptelaag hiervan aandag te gee. ${ }^{11}$ Die reaksie teen 'n mensbeskouing wat uitgaan van 'n verselfstandigde essensie of wese van die mens lei by Ellis as rasioneel-emotiewe psigoloog tot 'n gebrek aan ' $n$ visie op die mens as religieuse persoonlikheid, met die gevolg dat duidelik gestel word "... that we'd better not rate ourselves, our essence, or our being but only our deeds, acts and performances". (Ellis, 1979:47.) En die remedie vir die mens se irrasionele oortuigings is volgens Ellis (1979:28-29) 'n kognitiewe bewustheid van die irrasionele aard daarvan, en 'n filosofiese herstrukturering, wat impliseer dat sy denke in die tradisie van die Verligting staan, 'n tradisie wat aan die menslike rede verlossingskrag toeken.

\footnotetext{
"'Kleiner, (1979:189) kritisecr Ellis dan ook vanweë sy negatiwiteit tecnoor 'n 'spiritucle' benadering. Elders (Dolliver, 1979:207) word gewys op Ellis se siening van godsdiens as infanticle alhanklikheid, wat mel Freud se beskouings ooreenkoms toon.
} 


\section{GEVOLGTREKKINGS}

Dit blyk duidelik dat beide dieptepsigologiese en behavioristiese rigtings, ten spyte van opvallende verskille in benadering, gebaseer is op ' $n$ mensbeeld wat in hoofsaak as deterministies getipeer moet word. Dit blokkeer by Freud, sowel as by Watson en Skinner, by voorbaat 'n besef van die belang van die sinvraag, hoewel ' $n$ implisiete beantwoording van hierdie vraag in hul teorieë meespeel. Dit gebeur naamlik deur henede-normatiewe fasette soos die biotiese en die psigiese te verhef tot oorsprongsidee van waaruit menslike funksionering ontspruit. Hierdeur word tegelykertyd die verskeidenheid in menslike motiverings op monistiese wyse gereduseer tot 'n enkelvoudige funksioneringswyse van of drange of aangeleerde gewoontes, wat op geen wyse die religieuse gerigtheid van die mens verreken nie. In ooreenstemming hiermee word identiteit vereenselwig met die benede-normatiewe neerslag van natuurnoodwendighede of van eksterne kulturele noodwendighede (in die vorm van leerprosesse waaroor die mens geen beheer het nie) op die mens se persoonlikheid.

Die tempering van klassieke Freudiaanse en behavioristiese opvattings wat deurgaans in die nuwere verwerkings van hierdie rigtings sigbaar word, moet positief waardeer word, omdat die reduksionisme van die aanvanklike uitbouers daarvan in 'n belangrike mate hokgeslaan word. Hierdeur kom 'n vollediger visie op die mens na vore en word sy gedetermineerdheid grootliks in ewewig gehou deur 'n klem op die vryheid van tipies menslike beslissingsmoontlikhede.

'Tot 'n werklik reformatoriese siening van sin en identiteit kan 'n mens egter nie kom deur reduksionistiese beskouings soos dié van Freud en die oorspronklike behavioriste aan te vul deur en te versag met aandag aan fasette van menslike vryheid, soos neofreudiane en neo-behavioriste doen, nie. Dit het hoogstens 'n dualisme tot gevolg, wat dreig om die psigoloog se beskouings uiteen te skeur en heen en weer te laat skipper tussen determinisme en vryheid, net om per slot van rekening tog weer die voorrang alan eersgenoemde toe te ken en daarmee blyke te gee van die onmoontlikheid om volledig te ontkom aan die oorspronklike denkraamwerk waarbinne hul standpunte ontwikkel is.

Met hierdie kritiek word egter geensins bedoel dat die beskouings van die psigoloë onder bespreking waardeloos is en dat dit geen doel dien om daarvan kennis te neem nie. Inteendeel, van sowel natuurlike drange - wat volgens Christelike standpunt gesien moet word as legitieme menslike funksionerings, mits dit onder korrekte normatiewe leiding geplaas word - asook van die rol van leerprosesse en die invloed van alierlei 
kulturele faktore in identiteitsvorming moet rekenskap gegee word binne 'n eie geïntegreerde siening en paradigma. Dit vra egter ook openheid vir menslike beginselgebonde en normatiewe keusevryheid vanuit 'n basiese lewensgerigtheid.

\section{BIBLIOGRAFIE}

ADLER, A. 1948. What life should mean to you. Londen : George Allen \& Unwin.

ADLER, A. 1950. De rin van het leven. Geoutoriseerde vertaling van P.H. Ronge. Utrecht : Erven J. Bijleveld.

ALLEN, R.E., red. 1960. Greck philosophy: Thales to Aristotle. New York: The Free Press.

ALLPORT, G.W. 1961. Pattern and growth in personality. New York : Holt, Rinehart and Winston.

ANSHEN, R. 1965. Ongetitelde inlciding. (In Fromm, E. The heart of man: its genius for good and evil London : Routledge \& Kegan Paul. p. 7.)

DOLLIVER, R.H. 1979. The relationship of rational-emotive therapy to other psychotherapics and personality theorics. ( $m$ Ellis, A. \& Whitclcy, J.M., reds. Theoretical and empirical foundation of rational-emotive therapy. Montcrcy, Calif. : Brooks/Cole. p. 203-217.)

DOOYEWEERD, H. 1953 (1); 1955 (2); 1957 (3). A ncw critique of theoretical thought. (Translated by D. Freeman and B. Young.) Philadelphia: The Presbyterian and Reformed Publishing Co.

DU PLESSIS, W.F. 1982. Sinvolheidsbelewing, psigiese lyding en psigotcrapie. Psigoflitse: bulletin van die Departement Psigologie van die PU vir CHO, 4(1):15-18.

ELLIS, A. 1979. Rational-emotive therapy as a new theory of personality and therapy. (In Ellis, A. Whiteley, J.M., reds. Theoretical and empirical foundations of rational-emotive therapy. Montcrey, Calif. : Brooks/Colc. p. 1-100.)

ERIKSON, E.H., 1972. Growh and crisis of the healthy personality. (In Lazarus, R.S. \& Opton Jr, E.M., reds. Personality: sclected readings. Harmondsworth : Penguin. p. 167-213.)

ERIKSON, E.H. 1980. Identity and the life cycle. New York: Norton.

FRANKL. V.E. 1969. The will to meaning: foundations and applications of logotherapy. New York : World Publishing Co.

FREUD, S. 1972. (iesammelte Werke, XIII. Londen : Imago.

FROMM, E. 1965. The heart of man: its genius for good and evil. London : Routledge \& Kegan Paul.

GROSZ, (3. 1930. Uber alles dic Licbe: 60 neue Zeichnungen. Berlin : Bruno Cassirer.

HORNEY, K. 1947. The ncurotic personality of our time. London : Kegan Paul.

HUSSERL, E, 1977. Dic Krisis der curopäischen Wissenschaften und die transzendentale Phänomenologic. Hamburg : Felix Mciner.

JUNG, C. (3. 1954. Welt der Psyche: eine Auswahl zur Einführung. Zürich : Rascher.

KELLY, (j.A. 1963. A theory of personality: the psychology of personal constructs. New York : Norton.

KLEINER, F.B. 1979. Commentary on Albert Ellis' article. (In Ellis, A. \& Whitelcy, J.M., reds Theorctical and empirical foundations of rational-emotive therapy. Montercy, Calif. : Brooks/Colc. p. 188-192.)

MEYER, W.F. 1985. Ontwikkelingsteoriece. (In Louw, D.A., Gerdes, L.C. en Meyer, W.F. reds. Menslike ontwikkeling. Pretoria : HAUM. p. 106-148.)

MöLLER, A.T. 1987. Freud en dic psigoanalise. (In Möller, A.T., red. Persoonlikhcidsielkunde. Durban : Butterworth. p. 22-54.)

MöLLER, A.T. \& LOUW, (i.P. 1987. Kelly en Ellis - twec kogniticwe benaderings tot persoonlikheid. (In Möller, A.T., red. Persoonlikhcidsiclkunde. Durban : Butterworth. p. 85-121.)

SKINNER, B.F. 1972a. Bcyond freedom and dignity. London : Jonathan Cape. 
SKINNER, B.F. 1972b. Cumulative record: a selection of papers. 3rd ed. New York : Meredith WATSON, J.B. 1925. Bchaviorism. New York: The People's Institute. 